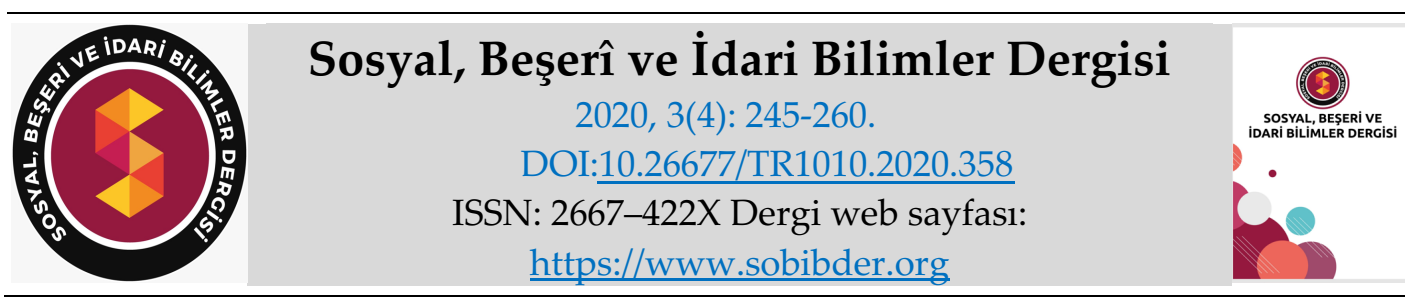

ARAȘTIRMA MAKALESİ

\title{
0-6 Yaş Aralığındaki Çocukların Gelişimlerinin Annelerinin Çocukluk Çağı Örselenme Yaşantıları ve Aile Yaşam Kaliteleri Açısından İncelenmesi*
}

Uzm. Çocuk Gelişimci Merve ÖZDEMİR, Atatürk Şehir Hastanesi, Balıkesir, e-posta: m.sener06@hotmail.com

ORCID: https://orcid.org/0000-0002-1194-2066

Doç. Dr. Haktan DEMIRCİĞLU, Hacettepe Üniversitesi, Sağlık Bilimleri Fakültesi, Ankara, eposta: hdemircioglu@hacettepe.edu.tr

ORCID: https://orcid.org/0000-0002-5092-1698

Öz

$\mathrm{Bu}$ araştırmanın amacı, 0-6 yaş aralığındaki çocukların gelişimlerini annelerinin çocukluk örselenme yaşantısı ve aile yaşam kaliteleri açısından incelemektir. Araştırma nicel yöntemlerden tarama modeline göre tasarlanmışır. Araştırmanın örneklemi, 202 anne ve onların 0-6 yaş arası çocuklarından ( $82 \mathrm{kız}$ ve 120 erkek) oluşmaktadır. Araştırmanın verileri; Aile Bilgi Formu, Çocukluk Örselenme Yaşantısı Ölçeği, Beach Center Aile Yaşam Kalitesi Ölçeği ve Denver Gelişimsel Tarama Testi II ile toplanmıştır. Verilerin analizi yapılırken Çok Gözlü Ki-Kare Testi ve Kruskal-Wallis H Testi kullanılmıştır. Araştırma sonucunda çocukların okul öncesi eğitim almaları ve annelerinin eğitim düzeyinin yükselmesinin çocukların gelişimleri üzerinde yordayıcı bir güce sahip olduğu; çocukların ince motor gelişimlerinin, annelerinin duygusal ve finansal aile yaşam kaliteleri açısından -artış gösteren grup lehine- anlamlı düzeyde olumlu seyrettiği görülmüştür. Elde edilen bulgular literatür çerçevesinde tartışılmıştır.

*Bu makale, Merve Özdemir'in Hacettepe Üniversitesi Sağlık Bilimleri Enstitüsü'nde hazırladığı ‘0-6 Yaş Arası Çocukların Gelişim Düzeyleri ile Annelerinin Örselenme Yaşantıları ve Aile Yaşam Kaliteleri Arasındaki İlişkinin İncelenmesi' isimli yüksek lisans tezinin bir kısmından üretilmiştir.

Anahtar Kelimeler: Çocuk Gelişimi, Okul Öncesi Dönem, Anne, Örselenme Yaşantısı, Aile Yaşam Kalitesi.

Makale Gönderme Tarihi: 16.12 .2019

Makale Kabul Tarihi: 01.04.2020

\section{Önerilen Atıf:}

Özdemir, M. ve Demircioğlu, H. (2020). 0-6 Yaş Aralığındaki Çocukların Gelişimlerinin Annelerinin Çocukluk Çağı Örselenme Yaşantıları ve Aile Yaşam Kaliteleri Açısından İncelenmesi, Sosyal, Beşeri ve İdari Bilimler Dergisi, 3(4): 245-260.

(c) 2020 Sosyal, Beşerî ve İdari Bilimler Dergisi. 


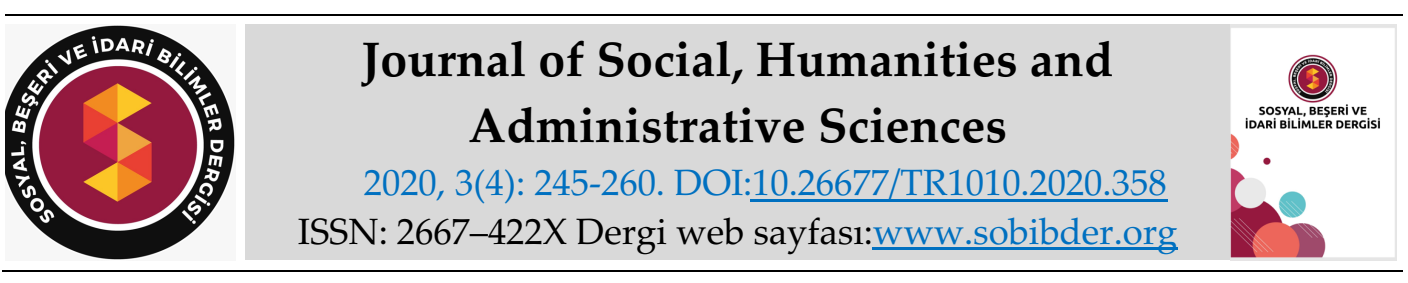

RESEARCH PAPER

\title{
Examination of the Development of Children Between the Ages of 0-6 in terms of Abuse Experiences and Life Quality of Their Mothers
}

\author{
Merve ÖZDEMIR, Atatürk City Hospital, Balıkesir, e-mail: m.sener-06@hotmail.com \\ ORCID: https://orcid.org/0000-0002-1194-2066
}

Associate Prof. Dr. Haktan DEMIRCIOĞLU, Hacettepe University, Faculty of Health Sciences, Ankara, e-mail: hdemircioglu@hacettepe.edu.tr

ORCID: https://orcid.org/0000-0002-5092-1698

\begin{abstract}
The aim of this research is to examine the development of children in the age range of 0-6 years in terms of their mother's childhood life and family life quality. The research is designed based on the model of screening test from quantitative methods. The sample of the study consists of 202 mothers and their children between the ages of 0-6 (82 girls and 120 boys). The data of the study were collected through family Data Form, Childhood Abuse Experience Scale, Beach Center Family Quality of Life Scale, and Denver Developmental Screening Test II. Multi-span Chi-Square Test and Kruskal-Wallis $\mathrm{H}$ test were used to analyze the data. The results of the study revealed that the children's pre-school education and education status of their mothers had a predictive power over their children's development; fine motor developments of the children were significantly positive in terms of their mothers' emotional and financial family quality of life - in favor of the group that showed an increase. The findings were discussed within the framework of the literature.
\end{abstract}

Keywords: Child Development, Preschool Period, Mother, Abuse Experience, Family Quality of Life.

Received: 16.12 .2019

Accepted: 01.04.2020

\section{Suggested Citation:}

Özdemir, M. and Demircioğlu, H. (2020). Examination of the Development of Children Between the Ages of 0-6 in terms of Abuse Experiences and Life Quality of Their Mothers, Journal of Social, Humanities and Administrative Sciences, 3(4): 245-260.

(c) 2020 Sosyal, Beşerî ve İdari Bilimler Dergisi. 


\section{Gíriş}

Bireyin gelecekteki yaşamının temellerinin atıldığı 0-6 yaş dönemi gelişim açısından oldukça önemlidir. Bebeğin doğumundan sonraki ilk yıllarda, ailenin çocuğu ile kurduğu ilişkinin, iletişimin niteliği ve çocuğun tecrübe edinmesi için fırsatların sunulması, çocuğun özgüvenli, etrafıyla sağlıklı bağ kurabilen toplum içinde yarar sağlayan, üretken bir birey olmasında etkili olmaktadır (Bracha vd., 2004). Bu bağlamda, çocuğun doğduğu andan başlayarak çok yönlü gelişimin gerçekleştiği toplumun en küçük birimi olan aile oldukça önemlidir (Şahin Dağlı, 2017). Ailenin çocuğun varlığından mutluluk duyuyor olması ve kendi içinde olumlu ilişkiler kurabilen yetişkinlerin varlığ çocuğun kendine olan güveninin gelişmesinde önemli rol oynamaktadır (Ünver Bağcioğlu, 2015).

Bebeğin, anne ile doğum öncesi başlayan ilişkisi doğum sonrasında emme ihtiyacının bu sürece dahil olmasıyla daha da önem kazanmaktadır (Yavuzer, 2007). Bebeklerin annelerine gösterdikleri bağlılık, hayatın başlangıcında gözlemlenen ilk sosyal davranıştır. Yeni doğanın anneye bağlılığı; sürekli ona yakın olma isteği, sarılması ve sürekli anneyi izlemesi açıkça görülebilir (Yavuzer, 2008). Annenin bebeğin ilgi ve ihtiyaçlarını önemseyerek, geciktirmeden ve zamanında karşılaması bebeğin temel güven duygusunun gelişmesine katkıda bulunmakla birlikte bebeğin gelecekte sağlıklı ilişkiler kurmasında etkili olacaktır (Yavuzer, 2007).

Bebeklik dönemindeki güvensiz bağlanmanın, annenin geçmişten getirdiği psikososyal sorunlar ile ilişkisi olduğu düşünülmektedir. Dolayısıyla annenin evliliğiyle ilgili düşünceleri, sosyal çevresinin kısıtlılı̆̆ı, psikolojik sorunları ve kendi çocukluk yaşantısı çocuğun anneye bağlanmasını fazlasıyla etkilemektedir (Bee vd., 1985). Özellikle çocukluk çağında örselenmiş ebeveynler yakın ilişkiler kurmakta güçlük çekmekte ve çatışmalı, duygusal yoğunluğu az, etrafındaki insanlarla ilişkisinde yıkıcı ve istismar edici yaklaşım gösterirler (Kaplan vd., 1999). İstismarın erken dönem etkilerinin yanı sıra yetişkinlik döneminde psikiyatrik bozukluklar, uyku bozuklukları, intihar eğilimi, madde kullanımı ve ebeveynlikte istismar etme durumları ile karşılaşılma olasılığı yüksektir (Diaz, Simantov ve Rickert, 2002).

Hem toplum hem de birey için büyük önem taşıyan aile, özellikle bireyin gelişimi açısından pek çok etkiye sahiptir. Aileyi etkileyen her durum, çocuk üzerinde de uzun veya kısa vadede etkili olmaktadır. Aile sistemini bozan etmenler çocuğun gelişiminde de aynı olumsuz etkiyi yaratabilmektedir. Çocuğun gelişiminde aile dinamiklerinin, ebeveynin geçmişinin, ebeveynin kişilik özelliklerinin ve çocuk yetiştirme tutumlarının önemli etkilerinin olduğu bilinmektedir (Belsky, 1980; Cicchetti ve Lynch, 1993).

Çocuğun aile ortamında maddi ve manevi gereksinimlerinin önemsenip, zamanında karşılanmasının çocukta yarattığı desteklenme duygusu sonucunda çocuğun aile ve toplumsal bakımdan yaşam kalitesi algısı etkilenmektedir. Aile yaşam kalitesi algısını etkileyen başka etmenlerde vardır. Bunlar; bireyin ailedeki her bireyle nitelikli ve güzel zaman geçirebilmesi, ailedeki bireylerin birbirlerine karşı yakın davranması ve destekleyici olması, ailedeki üyelerin karşılaşılan sorunlara çözüm odaklı yaklaşabilmeleri, eğitim ve sağlık gibi hizmetlerden faydalanabilme fırsatı sunulabilmesi ve aile bireylerinin güvenli, rahat bir ortamda yaşayabilmesidir (Andrews ve Withey, 1976; Campbell vd., 1976).

Anne ve babanın, birbirlerine ve çocuklarına ihtiyaçları olan ilgiyi göstermeleri ve ailedeki bireylerin rolleri ile ilgili sorumluluklarını yerine getirmek için çabalamaları, aile bağının sağlıklı bir şekilde oluşmasını sağlayacaktır (Masalcı, 2000). Bununla birlikte, çocuğun kendisi ve çevresiyle barışık bir birey olarak yetişmesi de ailenin gerçekleştirdiği bir olaydır. Duruma bu açıdan bakınca, topluma sağlıklı insan kazandıran "aile kurumu"nun oldukça önemli bir pozisyona sahip olduğu görülmektedir (Öz, 2003). Buradan yola çıkarak araştırmada 0-6 yaş 
dilimi içerisindeki çocukların gelişimlerinin annelerinin çocukluk çağı örselenme yaşantıları ve aile yaşam kaliteleri açısından incelenmesi amaçlanmıştır.

\section{YÖNTEM}

\section{Araştırmanın Türü}

Bu araştırmada 0-6 yaş arası çocukların gelişimlerinin, annelerinin çocukluk çağı örselenme yaşantıları ve annelerinin yaşam kaliteleri açısından incelenmesi amaçlanmıştır. Bu amaç doğrultusunda çalışma, nicel araştırma yöntemlerinden mevcut durumu ortaya koymayı hedefleyen tarama modeline göre tasarlanmıştır. Tarama modelinde bağımsız değişkenlerin bağımlı değişkenleri ne düzeyde açıkladığını ortaya koymak amaçlanırken ilişkisel modelde iki veya daha çok değişken arasındaki birlikte değişim varlığını ve derecesini belirlemek amaçlanır.

\section{Evren ve Örneklem}

Araştırmanın evrenini tespit edebilmek amacıyla, Balıkesir Merkez Atatürk Şehir Hastanesi "Çocuk Gelişimi Polikliniği" ne gelişimsel değerlendirme için son bir yıl içerisinde (01.12.201701.12.2018 tarihleri arasında) başvurusu yapılan 0-6 yaş dilimi içerisinde kaç çocuğun olduğu araştırılmıştır. Bu kapsamda, 1069 çocuk ve annesi araştırmanın evrenini oluşturmuştur.

Araştırma örnekleminde yer alacak anne ve çocuk sayısı Israel (1992) tarafından önerilen örneklem sayısı belirleme tablosu üzerinden; \% 95 güven aralığına ve $\% 5$ hassasiyet düzeyine göre hesaplanmış ve 291 çocuğun araştırmanın örneklemini oluşturabileceği görülmüştür. Bununla birlikte veri kaybı riski gözetilmiş; bu nedenle de araştırmanın örnekleminde Balıkesir Merkez Atatürk Şehir Hastanesi "Çocuk Gelişimi Polikliniği"ne gelişimsel değerlendirme için başvuran 0-6 yaş aralığında bulunan 300 çocuk ve annesinin yer alması öngörülmüştür. Ancak, araştırmanın başında 300 olarak belirlenen örneklem sayısı, veri toplama sürecinde başvuru yetersizliği nedeniyle 202 olarak değiştirilmiştir.

\section{Veri Toplama Araçları}

Araştırmada, ailenin demografik özelliklerini belirleyebilmek amacıyla "Aile Bilgi Formu", annelerin çocukluk örselenme yaşantılarını değerlendirebilmek amacıyla "Çocukluk Çağı Örselenme Yaşantısı Ölçeği (ÇÖYÖ)", annelerin aile yaşam kalitelerini değerlendirebilmek amacıyla "Beach Center Aile Yaşam Kalitesi Ölçeği (BCAYKÖ)" ve 0-6 yaş arası çocukların gelişim düzeylerini ölçmek amacıyla "Denver II Gelişimsel Tarama Testi" kullanılmıştır.

\section{Aile Bilgi Formu}

Araştırmaya katılan çocuklar, anneleri ve babaları ile ilgili demografik bilgileri edinmek amacıyla araştırmacı tarafından "Aile Bilgi Formu" hazırlanmıştır. Aile Bilgi Formu; çocukların yaş, cinsiyet doğum sırası, okul öncesi eğitim alma durumu, anne ve babanın yaşı, evlenme yaşı, çocuk sayısı, öğrenim durumu, çalışma durumları, mesleği, ekonomik durumları, babanın çocukla ilgilenme düzeyi ile ilgili bilgilerin ortaya konulmasına yönelik maddeleri kapsamaktadır. 


\section{Çocukluk Örselenme Yaşantısı Ölçeği (ÇÖYÖ)}

Ölçek, 18 yaş öncesindeki örselenme yaşantılarını araştırmak amacıyla 1994 yılında Bernstein ve arkadaşları (Bernstein vd., 1994) tarafından geliştirilmiş olup 5'li likert tipinde 40 maddelik bir ölçektir. Tüm maddeler "Hiçbir Zaman”, "Nadiren”, "Bazen”, "Sıklıkla” ve "Çok Sık” seçenekleri ile değerlendirilmektedir. Ölçeğin Türkçe' ye uyarlaması Aslan ve Alparslan (Aslan ve Alparslan, 1999) tarafından, Bernstein'dan izin alınarak yapılmıştır. Ölçeğin iç güvenirlik çalışması neticesinde Cronbach alfa katsayısı 0.96, alt ölçeklerin ise 0.94-0.96 arasında bulunmuştur. Faktör analizi sonucunda ölçeğin üç faktörlü bir yapı gösterdiği belirlenmiştir. Bu faktörler "duygusal kötüye kullanım ve duygusal ihmal", "fiziksel kötüye kullanım" ve "cinsel kötüye kullanım"dır. Ölçekten en düşük 40 puan, en yüksek 200 puan alınabilmektedir.

Verilerin toplanması için hastanenin bağlı olduğu müdürlüğün etik kuruluna başvuru sonrasında, etik kurul tarafından; araştırmaya katılanların ölçeğin cinsel istismar alt boyutu ile ilgili sorulara verilen yanıtların gerçeği yansıtmayacağı düşüncesi nedeniyle bu alt boyutun araştırma dışında tutulması istenmiştir. Bu nedenle ölçekte yer alan "duygusal kötüye kullanım ve duygusal ihmal" ve "fiziksel kötüye kullanım" alt boyutlarıyla çalışılmıştır. Yani ölçek 35 soru 2 alt boyut üzerinden puanlanmıştır. Bu haliyle ölçekten en yüksek 175 puan, en az ise 35 puan alınabilmektedir.

\section{Beach Center Aile Yaşam Kalitesi Ölçeği (BCAYKÖ)}

Ölçek, Kansas Üniversitesi Beach Aile ve Yetersizlik Merkezi tarafından herhangi bir gelişimsel yetersizliğe sahip olan çocukların ebeveynlerine yönelik hazırlanmıştır (Meral ve Cavkaytar, 2013). 5'li likert tipi olan ölçek toplam 25 maddeden oluşmaktadır. Ayrıca "aile etkileşimi boyutu (6 madde)", "ebeveynlik boyutu (6 madde)", "duygusal yeterlik boyutu (4 madde)", "fiziksel / finansal /materyal yeterliği (5 madde) ve "yetersizliğe ilişkin destek (4 madde)" alt boyutlarından oluşan ölçeğin toplam 5 alt boyutu vardır. Ölçeğin Türkçe uyarlaması ile geçerlilik ve güvenirlik çalışmaları Meral ve Cavkaytar (2013) tarafından yapılmıştır. Tüm maddeler "Hiç uygun değil", "Uygun değil", "Ne uygun ne uygun değil", "Uygun", "Tamamen uygun" değerlendirilmekte ve ters madde bulunmamaktadır. Ölçekten en yüksek 125 puan, en az ise 25 puan alınabilmektedir (Meral ve Cavkaytar, 2013). Ölçeğin iç güvenirlik çalışması neticesinde Cronbach alfa katsayısı 0.94'dir. Alt boyutlara ait olan Cronbach Alfa değerleri ise 0.80-0.92 arasında bulunmuştur (Meral, 2011). Bu tez çalışmasının örneklemini normal gelişim gösteren çocukların oluşturması nedeniyle ölçek 21 soru 4 alt boyut üzerinden puanlanmıştır. Yani "yetersizliğe ilişkin destek" alt boyutu araştırmaya dahil edilmemiştir. Bu haliyle ölçekten en yüksek 105 puan, en az ise 21 puan alınabilmektedir.

\section{Denver Gelişimsel Tarama Testi II}

Test, çocukların gelişimlerinin izlenerek gelişimsel sorunları yakalamak ve erkenden müdahale edebilmek amacıyla ilk kez 1967 yılında, Frankenburg ve Dodds tarafından yayınlanmıştır. Birçok ülkede kullanılmış ve elde edilen yeni bilgiler ışığında 1990 yılında Frankenburg ve Dodds tarafından yeniden gözden geçirilerek Denver II oluşturulmuştur. Türkiye'de 1982 yılında Hacettepe Üniversitesi öğretim üyeleri Kalbiye Yalaz ve Shirley Epir tarafından DGTT'nin ilk standardizasyonu yapılmıştır. 1996 yılında Kalbiye Yalaz ve Banu Anlar; 2009 yılında Kalbiye Yalaz, Banu Anlar ve Birgül Bayoğlu tarafından yeniden gözden geçirilmiş ve standardize edilmiştir. Denver II adıyla tüm Türkiye'de eğitimini almak şartıyla kullanıma sunulmuştur (Anlar ve Yalaz, 1996, Yalaz v.d., 2016). Denver II, kişisel-sosyal, ince motor-uyumsal, dil ve kaba 
motor olmak üzere dört gelişim alanını değerlendiren 134 maddeden oluşmaktadır. Çocuğun yaşı hesaplandıktan sonra yaş çizgisinin çizilmesiyle çocuğun hangi becerileri yapabilmesi gerektiği görülmekte ve bu şekilde testör çocuğun gelişiminin yaşı ile uyumunu değerlendirmektedir. Gelişimsel maddeler dışında testin sonunda gözlemlenen 5 adet "Test Davranışı" maddesi bulunmaktadır. Testör bu maddeleri çocuğu değerlendirdiği süre zarfında gözlemlemekte ve yorumsal olarak daha kolay değerlendirme yapabilmesini sağlayabilmektedir. Testin yorumlanmasında "normal", "anormal" ve "şüpheli" şeklinde üç değerlendirme bulunmaktadır. Çocuğun gelişiminin "normal" olarak yorumlanabilmesi için ayına/ yaşına uygun maddelerin hepsini geçmesi veya en fazla bir uyarı maddesi alması, "şüpheli" olarak yorumlanabilmesi için yalnızca bir gecikme, iki veya daha fazla uyarı, bir gecikme, bir gecikme + bir ve/veya daha fazla uyarı maddesi alması, "anormal" olarak yorumlanabilmesi için ise tüm testteki maddeler için iki veya daha fazla gecikme maddesi alması gerekmektedir. Bu tür anormal gelişim durumunda tanı değerlendirmesi için bir merkeze yönlendirme yapılması önerilmektedir (Yalaz vd., 2016).

\section{Araştırmanın Etik Yönü}

Öncelikle Beach Center Aile Yaşam Kalitesi Ölçeği ve Çocukluk Örselenme Yaşantısı Ölçeği'nin araştırma kapsamında kullanılabilmesi için ölçeklerin uyarlama çalışmasını yapan araştırmacılar ile iletişime geçilerek gerekli izinler alınmıştır. Bunun yanı sıra Denver Gelişimsel Tarama Testi II'nin uygulama eğitimi araştırmacı tarafından 2010 yılında alınmıştır.

Hacettepe Üniversitesi Etik Komisyonu ve Balıkesir İl Sağlık Müdürlüğü'nden gerekli izinlerin alınmasının ardından çalışmalara başlanmıştır.

\section{Veri Toplama İşlemi}

Araştırma hakkında bilgilendirilen ve katılmayı kabul eden anneler tarafından "Aile Bilgi Formu”, "Çocukluk Örselenme Yaşantıları Ölçeği" ve "Beach Center Aile Yaşam Kalitesi Ölçeği”" doldurulmuştur. Bu esnada annelerinin yanında bulunan çocuklarla iletişim kurularak "Denver II Gelişimsel Tarama Testi" uygulanmıştır.

\section{Verilerin Analizi}

Veriler SPSS 20.00 paket programına aktarıldıktan sonra analizleri yapılmıştır. Verilerin dağılımının normal olup olmadığını saptamak için örneklem büyüklügü 50'nin üzerinde olması sebebiyle Kolmogorov-Smirnov ve Shapiro Wilk testlerinden yararlanılmıştır. Veriler normal dağılım kriterine uymaması sebebiyle verilerin analizinde parametrik olmayan hipotez testlerinden yararlanılmıştır. Annelerin ve çocukların demografik bilgilerini Denver II sonuçları ile karşılaştırmak ve aralarındaki ilişkiyi incelemek amacıyla Ki-Kare ve Çok Gözlü Ki-Kare Testleri kullanılmıştır. Gruplar arasındaki farklılığın incelenmesinde; Kruskal-Wallis H testi kullanılmıştır. Hem normallik dağılım bulguları hem de hipotez testlerinin sonuçları yorumlanırken anlamlılık düzeyi olarak 0,05 olarak alınmıştır.

\section{BULGULAR}

Çalışma grubunda yer alan çocukların DGTT II'nin sonuçlarının çocukların demografik bilgilerine göre Ki-kare testi sonuçları Tablo.1'de yer verilmiştir. 
Tablo 1. DGTT II'nin sonuçlarının çocukların demografik bilgilerine göre Ki-kare testi sonuçları

\begin{tabular}{|c|c|c|c|c|c|c|}
\hline \multirow[t]{2}{*}{ Değişkenler } & \multirow[t]{2}{*}{ Gruplar } & \multicolumn{2}{|c|}{ Normal } & \multicolumn{3}{|c|}{ Normal Olmayan** } \\
\hline & & $\mathbf{f}$ & $\%$ & $\mathbf{f}$ & $\%$ & $\mathrm{p}$ \\
\hline \multirow{2}{*}{$\begin{array}{l}\text { Okul Öncesi Eğitim } \\
\text { Alma Durumu }\end{array}$} & Aliyor & 31 & 64,5 & 17 & 35,5 & , $048^{*}$ \\
\hline & Almiyor & 73 & 47,4 & 81 & 52,6 & \\
\hline \multirow[t]{3}{*}{ Cinsiyet } & $\mathrm{K} 1 \mathrm{z}$ & 49 & 59,7 & 33 & 40,3 & , 051 \\
\hline & Erkek & 55 & 45,8 & 65 & 54,2 & \\
\hline & 1 & 60 & 58,3 & 43 & 41,7 & \\
\hline \multirow[t]{2}{*}{ Doğum Sırası } & 2 & 34 & 44,2 & 43 & 55,8 & 188 \\
\hline & 3 ve sonrasi & 10 & 45,5 & 12 & 54,5 & \\
\hline
\end{tabular}

${ }^{*} \mathrm{p}<0,05$

**DGTT II sonucu "şüpheli" ve “anormal” olan çocuklar bu başlık altında toplanmıştır.

Tablo 2. DGTT II'nin sonuçlarının annelerin demografik bilgilerine göre Ki-kare testi sonuçları

\begin{tabular}{|c|c|c|c|c|c|c|}
\hline \multirow[t]{2}{*}{ Değişkenler } & \multirow[t]{2}{*}{ Gruplar } & \multirow{2}{*}{$\begin{array}{c}\text { Normal } \\
\mathrm{f} \\
\end{array}$} & \multicolumn{4}{|c|}{ Normal Olmayan** } \\
\hline & & & $\%$ & $f$ & $\%$ & $p$ \\
\hline \multirow{3}{*}{ Yaş } & 30 ve altı & 45 & 50,0 & 45 & 50,0 & 862 \\
\hline & 31-35 yaş & 38 & 53,5 & 33 & 46,5 & \\
\hline & 36 ve üstü & 20 & 48,7 & 21 & 51,3 & \\
\hline \multirow{4}{*}{ Evlenme yaşı } & 20 ve alt1 & 24 & 41,4 & 34 & 58,6 & 237 \\
\hline & $21-25$ yaş & 47 & 52,8 & 42 & 47,2 & \\
\hline & $26-30$ yaş & 22 & 62,9 & 13 & 37,1 & \\
\hline & 31 ve üstü & 10 & 50,0 & 10 & 50,0 & \\
\hline İlk Çocuğu & 20 ve alt1 & 13 & 40,6 & 19 & 59,4 & 433 \\
\hline \multirow[t]{2}{*}{ Doğurma Yaşı } & 21-25 yaş & 43 & 53,8 & 37 & 46,2 & \\
\hline & 26 ve üstü & 47 & 52,2 & 43 & 47,8 & \\
\hline \multirow{3}{*}{ Çocuk Sayısı } & 1 & 43 & 61,4 & 27 & 38,6 & \\
\hline & 2 & 47 & 48,0 & 51 & 52,0 & , 188 \\
\hline & 3 ve sonrası & 14 & 41,2 & 20 & 58,8 & \\
\hline \multirow{2}{*}{ Çalışma Durumları } & Çalışıyor & 32 & 59,3 & 22 & 40,7 & \\
\hline & Çalışmiyor & 71 & 47,9 & 77 & 52,1 & , 103 \\
\hline \multirow{6}{*}{ Meslek } & Çalışmıyor & 72 & 49,0 & 75 & 51,0 & \\
\hline & Kamu görevlisi & 18 & 64,3 & 10 & 35,7 & \\
\hline & İşçi & 3 & 37,5 & 5 & 62,5 & 173 \\
\hline & Serbest meslek & 2 & 33,3 & 4 & 66,7 & \\
\hline & Çiftçi & 0 & 0,00 & 2 & 100 & \\
\hline & Diğer & 8 & 72,7 & 3 & 27,3 & \\
\hline \multirow{4}{*}{ Öğrenim Durumu } & İlkokul ve öncesi & 10 & 32,3 & 21 & 67,7 & \\
\hline & Ortaokul & 23 & 46,0 & 27 & 54,0 &, $048^{*}$ \\
\hline & Lise & 30 & 53,6 & 26 & 46,4 & \\
\hline & Üniversite & 40 & 61,5 & 25 & 38,5 & \\
\hline
\end{tabular}

${ }^{*} \mathrm{p}<0,05$

Tablo 1. incelendiğinde, çocukların DGTT II'den aldıkları sonucun, onların cinsiyetlerine ve doğum sıralarına göre anlamlı bir farklılık göstermediği görülmektedir ( $p>0,05)$. Okul öncesi 
eğitim alıp almama durumlarına göre ise "okul öncesi eğitim alma" lehine anlamlı bir farklılık gösterdiği görülmektedir ( $p>0,05)$. Okul öncesi eğitim alan çocukların $(\% 64,5)$, okul öncesi eğitim almayan çocuklara $(\% 47,4)$ göre DGTT II'den daha yüksek oranda "normal" sonuç aldıkları saptanmıştır.

Tablo 2. incelendiğinde çocukların DGTT II sonuçlarının, annelerin yaşlarına, evlenme yaşlarına, ilk çocuğu doğurma yaşlarına, çocuk sayısına, çalışma durumlarına ve mesleklerine göre istatistiksel olarak anlamlı bir farklılık göstermediği ( $p>0,05)$; annelerin öğrenim durumuna göreyse çocukların DGTT II sonuçları arasında yükselen öğrenim kademesi lehine istatistiksel olarak anlamlı bir farklılık olduğu görülmektedir $(p<0,05)$. Üniversite mezunu annelerin çocukları (\% 61.5), ilkokul ve öncesi öğrenim durumuna sahip annelerin çocuklarına (\%32.3) göre DGTT II'den daha yüksek oranda "normal" sonuç aldıkları saptanmıştır. Eğitim kademesi yükseldikçe "normal" sonuçların yüzdesinde anlamlı düzeyde artış saptanmıştır.

Tablo 3. DGTT II'nin alt gelişim alanları ile ÇÖYÖ Fiziksel İstismar puan ortalamaları arasındaki Kruskal-Wallis $\mathrm{H}$ testi sonuçları

\begin{tabular}{|c|c|c|c|c|c|c|c|c|c|c|c|}
\hline $\begin{array}{l}\text { DGTT II } \\
\text { Gelişim } \\
\text { Alanları }\end{array}$ & $\begin{array}{l}\text { Fiziksel } \\
\text { İstismar }\end{array}$ & $\mathbf{n}$ & $\overline{\mathbf{X}}$ & Ortanca & Min & Max & ss & $\begin{array}{c}\text { Sira } \\
\text { Ortalaması }\end{array}$ & $\mathbf{H}$ & $\mathbf{p}$ & $\begin{array}{c}\text { İkili } \\
\text { Karşılaştırma }\end{array}$ \\
\hline \multirow{3}{*}{$\begin{array}{l}\text { Kişisel } \\
\text { Sosyal }\end{array}$} & Normal & 153 & 27,41 & 28 & 16 & 63 & 7,27 & 96,23 & \multirow{3}{*}{5,256} & \multirow{3}{*}{,072 } & \\
\hline & Uyarı & 15 & 30,53 & 30 & 20 & 44 & 8,11 & 122,0 & & & \\
\hline & Gecikme & 34 & 31,52 & 30 & 20 & 63 & 11,16 & 116,1 & & & \\
\hline \multirow{3}{*}{$\begin{array}{l}\text { İnce } \\
\text { Motor }\end{array}$} & Normal & 150 & 28,39 & 30 & 16 & 63 & 8,60 & 100,82 & \multirow{3}{*}{,598 } & \multirow{3}{*}{,742 } & \\
\hline & Uyarı & 19 & 29,05 & 30 & 20 & 45 & 7,53 & 111,3 & & & \\
\hline & Gecikme & 33 & 27,69 & 30 & 19 & 48 & 6,95 & 99,03 & & & \\
\hline \multirow{3}{*}{$\begin{array}{l}\text { Dil } \\
\text { Gelişim }\end{array}$} & Normal & 126 & 27,84 & 30 & 16 & 60 & 7,40 & 100,1 & \multirow{3}{*}{,206 } & \multirow{3}{*}{,902 } & \\
\hline & Uyarı & 12 & 31,16 & 30 & 19 & 63 & 13,52 & 101,3 & & & \\
\hline & Gecikme & 64 & 28,78 & 30 & 20 & 63 & 8,57 & 104,2 & & & \\
\hline \multirow{3}{*}{$\begin{array}{l}\text { Kaba } \\
\text { Motor }\end{array}$} & Normal & 164 & 28,05 & 30 & 16 & 63 & 7,60 & 100,7 & \multirow{3}{*}{3,975} & \multirow{3}{*}{ 137 } & \\
\hline & Uyarı & 8 & 35,62 & 35 & 24 & 60 & 13,82 & 140,6 & & & \\
\hline & Gecikme & 30 & 27,96 & 35 & 20 & 63 & 9,14 & 95,35 & & & \\
\hline
\end{tabular}

${ }^{*} \mathrm{p}<0,05$

Tablo 3. incelendiğinde annelerin ÇÖYÖ fiziksel istismar alt boyutu puan ortalamaları ile çocukların DGTT II dil gelişim, ince motor, kaba motor, kişisel sosyal beceri sonuçları arasında istatistiksel olarak anlamlı bir farklılık olmadığı görülmektedir $(p>0,05)$.

Tablo 4.'de annelerin ÇÖYÖ duygusal istismar-ihmal alt boyutu puan ortalamaları ile çocukların DGTT II dil gelişim, ince motor, kaba motor, kişisel sosyal beceri sonuçları arasında istatistiksel olarak anlamlı bir farklılık olmadığı görülmektedir ( $>>0,05)$.

Tablo 5.'de annelerin ÇÖYÖ toplam puan ortalamaları ile çocukların DGTT II dil gelişim, ince motor, kaba motor, kişisel sosyal beceri sonuçları arasında istatistiksel olarak anlamlı bir farklılık olmadığg görülmektedir ( $\mathrm{p}>0,05)$.

Tablo 6.'da annelerin BCAYKÖ aile etkileşimi alt boyutu puan ortalamaları ile çocukların DGTT II dil gelişim, ince motor, kaba motor, kişisel sosyal beceri sonuçları arasında istatistiksel olarak anlamlı bir farklılık olmadığı görülmektedir ( $p>0,05)$. 
Tablo 4. DGTT II'nin alt gelişim alanları ile ÇÖYÖ Duygusal İstismar-İhmal puan ortalamaları arasındaki Kruskal-Wallis $\mathrm{H}$ testi sonuçları

\begin{tabular}{|c|c|c|c|c|c|c|c|c|c|c|c|}
\hline $\begin{array}{l}\text { DGTT II } \\
\text { Gelişim } \\
\text { Alanları }\end{array}$ & $\begin{array}{l}\text { Duygusal } \\
\text { İstismar- } \\
\text { İhmal }\end{array}$ & $\mathbf{n}$ & $\overline{\mathbf{X}}$ & Ortanca & Min & Max & ss & $\begin{array}{c}\text { Sira } \\
\text { Ortalaması }\end{array}$ & $\mathbf{H}$ & $\mathrm{p}$ & $\begin{array}{c}\text { İkili } \\
\text { Karşılaştırma }\end{array}$ \\
\hline \multirow{3}{*}{$\begin{array}{l}\text { Kişisel } \\
\text { Sosyal }\end{array}$} & Normal & 153 & 66,59 & 66 & 29 & 87 & 11,78 & 104,6 & \multirow{3}{*}{2,433} & \multirow{3}{*}{,296 } & \\
\hline & Uyarı & 15 & 64,33 & 66 & 37 & 81 & 11,89 & 90,73 & & & \\
\hline & Gecikme & 34 & 62,91 & 66 & 30 & 79 & 13,78 & 89,32 & & & \\
\hline \multirow{3}{*}{$\begin{array}{l}\text { İnce } \\
\text { Motor }\end{array}$} & Normal & 150 & 66,13 & 66 & 29 & 87 & 12,53 & 103,8 & \multirow{3}{*}{1,803} & \multirow{3}{*}{,406 } & \\
\hline & Uyarı & 19 & 63,31 & 66 & 31 & 79 & 12,45 & 85,95 & & & \\
\hline & Gecikme & 33 & 65,75 & 66 & 43 & 81 & 10,38 & 96,82 & & & \\
\hline \multirow{3}{*}{$\begin{array}{l}\text { Dil } \\
\text { Gelişim }\end{array}$} & Normal & 126 & 66,65 & 66 & 29 & 87 & 11,26 & 103,3 & \multirow{3}{*}{1,160} & \multirow{3}{*}{, 560} & \\
\hline & Uyarı & 12 & 60,66 & 66 & 31 & 79 & 16,75 & 85,00 & & & \\
\hline & Gecikme & 64 & 65,10 & 66 & 30 & 81 & 12,82 & 99,42 & & & \\
\hline \multirow{3}{*}{$\begin{array}{l}\text { Kaba } \\
\text { Motor }\end{array}$} & Normal & 164 & 65,93 & 65 & 29 & 87 & 11,92 & 100,89 & \multirow{3}{*}{2,370} & \multirow{3}{*}{,306 } & \\
\hline & Uyarı & 8 & 58,87 & 60 & 30 & 73 & 16,44 & 73,38 & & & \\
\hline & Gecikme & 30 & 66,93 & 65 & 34 & 79 & 12,16 & 108,95 & & & \\
\hline
\end{tabular}

${ }^{*} \mathrm{p}<0,05$

Tablo 5. DGTT II'nin alt gelişim alanları ile ÇÖYÖ Toplam puan ortalamaları arasındaki Kruskal-Wallis H testi sonuçları

\begin{tabular}{|c|c|c|c|c|c|c|c|c|c|c|c|}
\hline $\begin{array}{l}\text { DGTT II } \\
\text { Gelişim } \\
\text { Alanları } \\
\end{array}$ & $\begin{array}{c}\text { ÇÖYÖ } \\
\text { Genel } \\
\text { Toplam }\end{array}$ & $\mathbf{n}$ & $\overline{\mathbf{X}}$ & Ortanca & Min & Max & ss & $\begin{array}{c}\text { Sıra } \\
\text { Ortalaması }\end{array}$ & $\mathbf{H}$ & p & $\begin{array}{c}\text { İkili } \\
\text { Karşılaştırma }\end{array}$ \\
\hline \multirow{3}{*}{$\begin{array}{l}\text { Kişisel } \\
\text { Sosyal }\end{array}$} & Normal & 153 & 94,03 & 94 & 52 & 110 & 9,97 & 101,5 & \multirow{3}{*}{1,636} & \multirow{3}{*}{,441 } & \\
\hline & Uyarı & 15 & 95,70 & 95 & 66 & 111 & 11,01 & 113,7 & & & \\
\hline & Gecikme & 34 & 93,93 & 94 & 76 & 120 & 8,72 & 91,75 & & & \\
\hline \multirow{3}{*}{$\begin{array}{l}\text { İnce } \\
\text { Motor }\end{array}$} & Normal & 150 & 94,43 & 94 & 52 & 120 & 10,02 & 103,2 & \multirow{3}{*}{,905 } & \multirow{3}{*}{,636 } & \\
\hline & Uyarı & 19 & 93,26 & 94 & 67 & 111 & 10,76 & 96,71 & & & \\
\hline & Gecikme & 33 & 93,47 & 94 & 70 & 120 & 8,65 & 93,46 & & & \\
\hline \multirow{3}{*}{$\begin{array}{l}\text { Dil } \\
\text { Gelişim }\end{array}$} & Normal & 126 & 94,52 & 95 & 66 & 120 & 9,54 & 102,4 & \multirow{3}{*}{,347 } & \multirow{3}{*}{841} & \\
\hline & Uyarı & 12 & 93,33 & 93 & 76 & 111 & 10,14 & 93,50 & & & \\
\hline & Gecikme & 64 & 93,62 & 93 & 52 & 109 & 10,48 & 99,91 & & & \\
\hline \multirow{3}{*}{$\begin{array}{l}\text { Kaba } \\
\text { Motor }\end{array}$} & Normal & 164 & 94,01 & 94 & 52 & 120 & 10,32 & 101,4 & \multirow{3}{*}{ 132 } & \multirow{3}{*}{,936 } & \\
\hline & Uyarı & 8 & 96,33 & 95 & 85 & 111 & 7,53 & 104,3 & & & \\
\hline & Gecikme & 30 & 94,34 & 95 & 74 & 120 & 7,59 & 97,69 & & & \\
\hline
\end{tabular}

${ }^{*} \mathrm{p}<0,05$

Tablo 6. DGTT II'nin alt gelişim alanları ile BCAYKÖ Aile Etkileşim puan ortalamaları arasındaki KruskalWallis $\mathrm{H}$ testi sonuçları

\begin{tabular}{|c|c|c|c|c|c|c|c|c|c|c|c|}
\hline $\begin{array}{l}\text { DGTT II } \\
\text { Gelişim } \\
\text { Alanları }\end{array}$ & $\begin{array}{c}\text { Aile } \\
\text { Etkileşim }\end{array}$ & $\mathbf{n}$ & $\overline{\mathbf{X}}$ & Ortanca & Min & Max & ss & $\begin{array}{c}\text { Sira } \\
\text { Ortalaması }\end{array}$ & $\mathbf{H}$ & $\mathbf{p}$ & $\begin{array}{c}\text { İkili } \\
\text { Karşılaştırma }\end{array}$ \\
\hline \multirow{3}{*}{$\begin{array}{l}\text { Kişisel } \\
\text { Sosyal }\end{array}$} & Normal & 153 & 26,20 & 26 & 6 & 30 & 3,69 & 103,4 & \multirow{3}{*}{2,367} & \multirow{3}{*}{,306 } & \\
\hline & Uyarı & 15 & 26,80 & 26 & 21 & 30 & 2,75 & 111,2 & & & \\
\hline & Gecikme & 34 & 24,97 & 26 & 10 & 30 & 4,56 & 88,29 & & & \\
\hline \multirow{3}{*}{$\begin{array}{l}\text { İnce } \\
\text { Motor }\end{array}$} & Normal & 150 & 26,34 & 26 & 6 & 30 & 3,68 & 106,1 & \multirow{3}{*}{3,824} & \multirow{3}{*}{,148 } & \\
\hline & Uyarı & 19 & 24,89 & 26 & 10 & 30 & 4,54 & 85,18 & & & \\
\hline & Gecikme & 33 & 25,36 & 26 & 15 & 30 & 3,87 & 89,77 & & & \\
\hline \multirow{3}{*}{$\begin{array}{l}\text { Dil } \\
\text { Gelişim }\end{array}$} & Normal & 126 & 26,22 & 26 & 6 & 30 & 3,58 & 102,4 & \multirow{3}{*}{,759 } & \multirow{3}{*}{ 684 } & \\
\hline & Uyarı & 12 & 23,91 & 26 & 10 & 30 & 6,66 & 87,38 & & & \\
\hline & Gecikme & 64 & 26,09 & 26 & 15 & 30 & 3,49 & 102,2 & & & \\
\hline \multirow{3}{*}{$\begin{array}{l}\text { Kaba } \\
\text { Motor }\end{array}$} & Normal & 164 & 26,18 & 26 & 6 & 30 & 3,84 & 104,2 & \multirow{3}{*}{2,438} & \multirow{3}{*}{,295 } & \\
\hline & Uyarı & 8 & 25,75 & 26 & 16 & 30 & 4,86 & 103,1 & & & \\
\hline & Gecikme & 30 & 25,36 & 26 & 15 & 30 & 3,38 & 86,27 & & & \\
\hline
\end{tabular}

${ }^{*} \mathrm{p}<0,05$ 
Tablo 7. DGTT II'nin alt gelişim alanları ile BCAYKÖ Ebeveynlik puan ortalamaları arasındaki Kruskal-Wallis $\mathrm{H}$ testi sonuçları

\begin{tabular}{|c|c|c|c|c|c|c|c|c|c|c|c|}
\hline $\begin{array}{l}\text { DGTT II } \\
\text { Gelişim } \\
\text { Alanları }\end{array}$ & Ebeveynlik & $\mathbf{n}$ & $\overline{\mathbf{X}}$ & Ortanca & Min & Max & ss & $\begin{array}{c}\text { Sira } \\
\text { Ortalaması }\end{array}$ & $\mathbf{H}$ & $\mathrm{p}$ & $\begin{array}{c}\text { İkili } \\
\text { Karşılaştırma }\end{array}$ \\
\hline \multirow{3}{*}{$\begin{array}{l}\text { Kişisel } \\
\text { Sosyal }\end{array}$} & Normal & 153 & 25,33 & 25 & 12 & 30 & 3,68 & 103,9 & \multirow{3}{*}{1,645} & \multirow{3}{*}{,439 } & \\
\hline & Uyarı & 15 & 25,40 & 25 & 16 & 30 & 4,54 & 102,6 & & & \\
\hline & Gecikme & 34 & 24,05 & 25 & 13 & 30 & 3,87 & 89,85 & & & \\
\hline \multirow{3}{*}{$\begin{array}{l}\text { İnce } \\
\text { Motor }\end{array}$} & Normal & 150 & 25,36 & 25 & 12 & 30 & 3,40 & 105,3 & \multirow{3}{*}{2,560} & \multirow{3}{*}{,278 } & \\
\hline & Uyarı & 19 & 24,31 & 25 & 16 & 30 & 3,75 & 90,24 & & & \\
\hline & Gecikme & 33 & 24,51 & 25 & 13 & 30 & 3,57 & 90,45 & & & \\
\hline \multirow{3}{*}{$\begin{array}{l}\text { Dil } \\
\text { Gelişim }\end{array}$} & Normal & 126 & 25,33 & 25 & 12 & 30 & 3,15 & 103,2 & \multirow{3}{*}{,415 } & \multirow{3}{*}{813} & \\
\hline & Uyarı & 12 & 24,91 & 25 & 15 & 30 & 4,46 & 104,1 & & & \\
\hline & Gecikme & 64 & 24,75 & 25 & 13 & 30 & 3,87 & 97,64 & & & \\
\hline \multirow{3}{*}{$\begin{array}{l}\text { Kaba } \\
\text { Motor }\end{array}$} & Normal & 164 & 25,35 & 25 & 12 & 30 & 3,21 & 103,8 & \multirow{3}{*}{4,033} & \multirow{3}{*}{,133 } & \\
\hline & Uyarı & 8 & 25,87 & 25 & 17 & 29 & 3,97 & 121,1 & & & \\
\hline & Gecikme & 30 & 23,66 & 25 & 13 & 30 & 4,38 & 83,53 & & & \\
\hline
\end{tabular}

${ }^{*} \mathrm{p}<0,05$

Tablo 7.'de annelerin BCAYKÖ ebeveynlik alt boyutu puan ortalamaları ile çocukların DGTT II dil gelişim, ince motor, kaba motor, kişisel sosyal beceri sonuçları arasında istatistiksel olarak anlamlı bir farklılık olmadığı görülmektedir $(\mathrm{p}>0,05)$.

Tablo 8. DGTT II'nin alt gelişim alanları ile BCAYKÖ Duygusal Yeterlik puan ortalamaları arasındaki Kruskal-Wallis H testi sonuçları

\begin{tabular}{|c|c|c|c|c|c|c|c|c|c|c|c|}
\hline $\begin{array}{l}\text { DGTT II } \\
\text { Gelişim } \\
\text { Alanları }\end{array}$ & $\begin{array}{l}\text { Duygusal } \\
\text { Yeterlik }\end{array}$ & $\mathrm{n}$ & $\overline{\mathbf{X}}$ & Ortanca & Min & Max & ss & $\begin{array}{c}\text { Sira } \\
\text { Ortalaması }\end{array}$ & $\mathbf{H}$ & p & $\begin{array}{c}\text { İkili } \\
\text { Karşılaştırma }\end{array}$ \\
\hline \multirow{3}{*}{$\begin{array}{l}\text { Kişisel } \\
\text { Sosyal }\end{array}$} & Normal & 153 & 15,24 & 15 & 12 & 30 & 3,68 & 106,7 & \multirow{3}{*}{5,090} & \multirow{3}{*}{,078 } & \\
\hline & Uyarı & 15 & 14,20 & 17 & 16 & 30 & 4,54 & 86,13 & & & \\
\hline & Gecikme & 34 & 13,91 & 15 & 13 & 30 & 3,87 & 84,78 & & & \\
\hline \multirow{3}{*}{$\begin{array}{l}\text { İnce } \\
\text { Motor }\end{array}$} & Normal & 150 & 15,42 & 15 & 4 & 20 & 3,09 & 108,9 & \multirow{3}{*}{11,652} & \multirow{3}{*}{,003* } & $1-2$ \\
\hline & Uyarı & 19 & 12,68 & 15 & 6 & 20 & 3,68 & 64,76 & & & $1-3$ \\
\hline & Gecikme & 33 & 14,06 & 15 & 4 & 20 & 3,93 & 88,70 & & & \\
\hline \multirow{3}{*}{$\begin{array}{l}\text { Dil } \\
\text { Gelişim }\end{array}$} & Normal & 126 & 15,20 & 15 & 6 & 20 & 3,08 & 104,6 & \multirow{3}{*}{,987 } & \multirow{3}{*}{,611 } & \\
\hline & Uyarı & 12 & 14,25 & 15 & 4 & 20 & 5,04 & 98,83 & & & \\
\hline & Gecikme & 64 & 14,56 & 15 & 4 & 20 & 3,64 & 95,87 & & & \\
\hline \multirow{3}{*}{$\begin{array}{l}\text { Kaba } \\
\text { Motor }\end{array}$} & Normal & 164 & 15,19 & 15 & 4 & 20 & 3,28 & 105,7 & \multirow{3}{*}{5,807} & \multirow{3}{*}{,055 } & \\
\hline & Uyarı & 8 & 14,87 & 15 & 8 & 18 & 3,68 & 103,9 & & & \\
\hline & Gecikme & 30 & 13,60 & 15 & 6 & 20 & 3,73 & 77,90 & & & \\
\hline
\end{tabular}

${ }^{*} \mathrm{p}<0,05$

Tablo 8.'de Beach Center Aile Yaşam Kalitesi Ölçeği'nin duygusal yeterlik alt boyutu puan ortalamaları ile çocukların DGTT II dil gelişim, kaba motor, kişisel sosyal beceri sonuçları arasında istatistiksel olarak anlamlı bir farklılık olmadığ ${ }_{1}(\mathrm{p}>0,05)$; duygusal yeterlik alt boyutu puan ortalamaları ile çocukların ince motor sonuçları arasında ise istatistiksel olarak anlamlı bir farklılık olduğu görülmektedir $(\mathrm{p}<0,05)$.

Söz konusu farklılığın hangi gruplarda meydana geldiğini ortaya koymak amaciyla ikili karşılaştırma yapılmış ve duygusal yeterlik alt boyutu ile çocuğun ince motor gelişim sonuçları; normal ile uyarı ve gecikme olanların arasında, normal olanların lehine istatistiksel olarak 
anlamlı bir farklılık olduğu görülmektedir $(\mathrm{p}<0,05)$. Bu bulgu üzerinden duygusal yeterliği daha az olan annelerin çocuklarının ince motor becerilerinde gecikmeler olduğu söylenebilir.

Tablo 9.'da Beach Center Aile Yaşam Kalitesi Ölçeği'nin finansal yeterlik alt boyutu puan ortalamaları ile çocukların DGTT II dil gelişim, kaba motor, kişisel sosyal beceri sonuçları arasında istatistiksel olarak anlamlı bir farklılık olmadığı $(p>0,05)$; finansal yeterlik puan ortalamaları ile çocukların ince motor sonuçları arasında ise istatistiksel olarak anlamlı bir farklılık olduğu görülmektedir $(\mathrm{p}<0,05)$.

Tablo 9. DGTT II'nin alt gelişim alanları ile BCAYKÖ Finansal Yeterlik puan ortalamaları arasındaki Kruskal-Wallis H testi sonuçları

\begin{tabular}{|c|c|c|c|c|c|c|c|c|c|c|c|}
\hline $\begin{array}{l}\text { DGTT II } \\
\text { Gelişim } \\
\text { Alanları }\end{array}$ & $\begin{array}{l}\text { Finansal } \\
\text { Yeterlik }\end{array}$ & $\mathbf{n}$ & $\overline{\mathbf{X}}$ & Ortanca & Min & Max & ss & $\begin{array}{c}\text { Sira } \\
\text { Ortalaması }\end{array}$ & $\mathbf{H}$ & p & $\begin{array}{c}\text { İkili } \\
\text { Karşılaştırma }\end{array}$ \\
\hline \multirow{3}{*}{$\begin{array}{l}\text { Kişisel } \\
\text { Sosyal }\end{array}$} & Normal & 153 & 20,89 & 20 & 8 & 25 & 3,85 & 103,89 & \multirow{3}{*}{1,290} & \multirow{3}{*}{, 525} & \\
\hline & Uyarı & 15 & 20,66 & 20 & 13 & 25 & 3,86 & 99,97 & & & \\
\hline & Gecikme & 34 & 19,91 & 20 & 11 & 25 & 4,41 & 91,44 & & & \\
\hline \multirow{3}{*}{$\begin{array}{l}\text { İnce } \\
\text { Motor }\end{array}$} & Normal & 150 & 21,18 & 20 & 8 & 25 & 3,65 & 107,58 & \multirow{3}{*}{6,483} & \multirow{3}{*}{,039* } & $1-2$ \\
\hline & Uyarı & 19 & 19,10 & 20 & 11 & 25 & 4,65 & 80,79 & & & $1-3$ \\
\hline & Gecikme & 33 & 19,51 & 20 & 11 & 25 & 4,40 & 85,79 & & & \\
\hline \multirow{3}{*}{$\begin{array}{l}\text { Dil } \\
\text { Gelişim }\end{array}$} & Normal & 126 & 20,89 & 20 & 9 & 25 & 3,62 & 102,1 & \multirow{3}{*}{1,171} & \multirow{3}{*}{, 557} & \\
\hline & Uyarı & 12 & 19,33 & 20 & 11 & 25 & 4,59 & 84,13 & & & \\
\hline & Gecikme & 64 & 20,60 & 20 & 8 & 25 & 4,42 & 103,5 & & & \\
\hline \multirow{3}{*}{$\begin{array}{l}\text { Kaba } \\
\text { Motor }\end{array}$} & Normal & 164 & 21,01 & 20 & 8 & 25 & 3,71 & 105,2 & \multirow{3}{*}{3,784} & \multirow{3}{*}{ 151 } & \\
\hline & Uyarı & 8 & 20,37 & 20 & 13 & 24 & 3,99 & 93,94 & & & \\
\hline & Gecikme & 30 & 19,13 & 20 & 9 & 25 & 4,86 & 83,22 & & & \\
\hline
\end{tabular}

${ }^{*} \mathrm{p}<0,05$

Söz konusu farklılığın hangi gruplarda meydana geldiğini ortaya koymak amacıyla ikili karşılaştırma yapılmış ve finansal yeterlik alt boyutu ile çocuğun ince motor gelişim sonuçları arasında; normal ile uyarı ve gecikme olması arasında normal sonucun lehine anlamlı bir farklılık olduğu görülmektedir $(\mathrm{p}<0,05)$. Bu bulgu üzerinden, finansal yeterliği daha az olan annelerin çocuklarının ince motor becerilerinde gecikmeler olduğu ifade edilebilir.

Tablo 10. DGTT II'nin alt gelişim alanları ile BCAYKÖ toplam puan ortalamaları arasındaki Kruskal-Wallis H testi sonuçları.

\begin{tabular}{|c|c|c|c|c|c|c|c|c|c|c|c|}
\hline $\begin{array}{c}\text { DGTT II } \\
\text { Gelişim } \\
\text { Alanları } \\
\end{array}$ & $\begin{array}{c}\text { BCAYKÖ } \\
\text { Genel } \\
\text { Toplam }\end{array}$ & $\mathbf{n}$ & $\overline{\mathbf{X}}$ & Ortanca & Min & Max & ss & $\begin{array}{c}\text { Sira } \\
\text { Ortalaması }\end{array}$ & $\mathbf{H}$ & $\mathrm{p}$ & $\begin{array}{c}\text { İkili } \\
\text { Karşılaştırma }\end{array}$ \\
\hline \multirow{3}{*}{$\begin{array}{l}\text { Kişisel } \\
\text { Sosyal }\end{array}$} & Normal & 153 & 87,68 & 87 & 59 & 105 & 11,07 & 104,7 & \multirow{3}{*}{2,296} & \multirow{3}{*}{,317 } & \\
\hline & Uyarı & 15 & 87,06 & 87 & 72 & 104 & 6,52 & 99,12 & & & \\
\hline & Gecikme & 34 & 82,85 & 82 & 46 & 105 & 14,29 & 87,05 & & & \\
\hline \multirow{3}{*}{$\begin{array}{l}\text { İnce } \\
\text { Motor }\end{array}$} & Normal & 150 & 88,30 & 88 & 57 & 105 & 11,15 & 109,0 & \multirow{3}{*}{10,213} & \multirow{3}{*}{, $004^{*}$} & $1-2$ \\
\hline & Uyarı & 19 & 81,00 & 80 & 46 & 96 & 11,48 & 66,89 & & & $1-3$ \\
\hline & Gecikme & 33 & 83,45 & 84 & 53 & 104 & 12,56 & 87,75 & & & \\
\hline \multirow{3}{*}{$\begin{array}{l}\text { Dil } \\
\text { Gelişim }\end{array}$} & Normal & 126 & 87,65 & 87 & 59 & 105 & 10,55 & 103,8 & \multirow{3}{*}{, 470} & \multirow{3}{*}{ 791 } & \\
\hline & Uyarı & 12 & 82,41 & 85 & 46 & 105 & 17,01 & 99,30 & & & \\
\hline & Gecikme & 64 & 86,01 & 85 & 53 & 105 & 12,30 & 98,02 & & & \\
\hline \multirow{3}{*}{$\begin{array}{l}\text { Kaba } \\
\text { Motor }\end{array}$} & Normal & 164 & 87,75 & 87 & 46 & 105 & 11,24 & 105,6 & \multirow{3}{*}{5,925} & \multirow{3}{*}{,053 } & \\
\hline & Uyarı & 8 & 86,87 & 87 & 57 & 99 & 12,79 & 104,7 & & & \\
\hline & Gecikme & 30 & 81,76 & 80 & 53 & 105 & 12,64 & 77,17 & & & \\
\hline
\end{tabular}

${ }^{*} \mathrm{p}<0,05$ 
Tablo 10.'da Beach Center Aile Yaşam Kalitesi Ölçeği'nin BCAYKÖ toplam puan ortalamaları ile çocukların DGTT II dil gelişim, kaba motor ve kişisel sosyal beceri sonuçları arasında istatistiksel olarak anlamlı bir farklılık olmadı $\breve{g} 1$ ( $>00,05)$; BCAYKÖ toplam puan ortalamaları ile çocukların ince motor sonuçları arasında ise istatistiksel olarak anlamlı bir farklılık olduğu görülmektedir $(\mathrm{p}<0,05)$.

Söz konusu farklılığın hangi gruplarda meydana geldiğini ortaya koymak amaciyla ikili karşılaştırma yapılmış ve BCAYKÖ toplam puan ortalamaları ile çocuğun ince motor gelişim sonuçları arasında; normal ile uyarı ve gecikme olması arasında normal sonucun lehine istatistiksel olarak anlamlı bir farklılık olduğu görülmektedir $(p<0,05)$. Bu bulgu temelinde, aile yaşam kalitesi daha düşük olan annelerin çocuklarının ince motor gelişimlerinde gecikmeler olduğu söylenebilir.

\section{TARTIŞMA}

Araştırma bulguları, çocuğun gelişiminin okul öncesi eğitim alma durumuna göre anlamlı düzeyde farklılaştığı sonucunu ortaya koymaktadır. Okul öncesi eğitim alan çocukların \%64,5 oranında "normal", okul öncesi eğitim almayan çocukların ise \%52,6 oranında "normal olmayan" gelişim gösterdikleri görülmüştür. Literatür incelendiğinde bu araştırma bulgusunu destekleyen çalışmalar mevcuttur. Şen ve arkadaşları (2010), üstdil becerileri analizi sonucunda, "Cümleyi Sözcüklerine Ayırma (CSA)", "Sözcüğü Hecelerine Ayırma (SHA)", "Verilen Sesle Başlayan Sözcüğü Bulma (BSB)" ve "Verilen Sesin Sonda Olduğu Sözcügü Bulma (SSB)" işlemlerinde, okul öncesi eğitim alan çocukların daha iyi gelişim gösterdiğini bulmuşlardır. Kök ve arkadaşları (2005), yaptıkları çalışmanın sonucunda; okul öncesi eğitim alan çocukların psiko-sosyal, dil, motor ve bilişsel gelişimi diğer öğrencilere kıyasla daha iyi bulunmuştur. Anlıak ve Dinçer (2005), okul öncesi eğitim kurumlarında farklı yaklaşımları barındıran eğitim programlarının kullanılması çocukların "problem çözme becerisi"ne ve "alternatif çözüm düşünme becerisi"ne etkisi olduğunu saptamışlardır. Okul öncesi eğitimin; çocukların gelişim alanlarını desteklemeye yönelik etkinlikleri barındırması, akran etkileşimine fırsat oluşturması, günlük yaşam becerilerinin kazanımına yardımcı olması ve bununla birlikte zengin uyaran sağlaması sonucunda çocukların gelişimini olumlu yönde etkilediği düşünülmektedir.

Annelerin öğrenim durumları ile çocukların gelişimi arasında istatistiksel olarak anlamlı bir farklılık olduğu görülmüştür. Üniversite mezunu annelerin çocuklarının Denver II gelişim sonucuna göre en yüksek oranda (\%61,5) "normal" gelişime, ilkokul mezunu annelerin çocukların en yüksek oranda (\%67,7) "normal olmayan" gelişime sahip oldukları görülmüştür. Eğitim düzeyi arttıkça annelerin çocuk gelişimi ile ilgili güncel yaklaşımları takip edip çocuklarının gelişimi ile ilgili daha bilinçli bir şekilde ilerlemeleri ve ayrıca çocuklarına sağladıkları uyaran çeşidinin artması da bu farklılığın bir diğer sebebi olarak düşünülmektedir. Söz konusu bulgunun ilgili literatürü desteklediği görülmektedir. Canbolat (2017), 48-72 aylık çocukların sosyal beceri ve problem davranışları ile ebeveynlerinin duygusal zekâ düzeyleri ve yaşam doyumları arasındaki ilişkiyi incelediği araştırmanın sonucunda annenin öğrenim durumuna göre farklılık gösterdiği bulunmuştur. Yener (2014), çocukların sosyal beceri düzeyleri ile annenin öğrenim durumu arasında anlamlı bir farklılık gösterdiğini bunun yanısıra annenin eğitim seviyesi düştükçe "aşırı koruyuculuk", "ev kadınlığ1 rolünü reddetme", "karı-koca geçimsizliği" ve "baskı ve disiplin" tutumlarında artış olduğu saptanmıştır. Kuyucu (2012), çocukların akranlarına karşı gösterdikleri "duygusal ve davranışsal tepkiler"in "duygu anlama becerisi" düzeyinin, çocuğun okul öncesi eğitim alma süresine, cinsiyetine, kardeş sayısına, anne ve baba eğitim durumuna ve ailenin gelirine göre farklılık gösterdiğini bulmuştur. Atış Akyol (2015), anne öğrenim durumu değişkeni ile ilkokula hazırbulunuşluk alt boyutlarından 
"matematik becerileri", "fen becerileri", "ses becerileri", "zihinsel dil gelişimi", "sosyal duygusal gelişim", "fiziksel gelişim" alt boyutları arasında anlamlı farklılık olduğunu saptamıştır. Anne eğitim düzeyi arttıkça çocukların matematik beceri düzeylerinin arttığı; annesi yükseköğretim mezunu olanların ortaöğretim ve ilköğretim mezunlarına göre ses becerilerinde, zihinsel-dil gelişiminde, sosyal-duygusal gelişiminde daha iyi olduğu bulunmuştur. Ayrıca annesi üniversite mezunu olan çocukların, anneleri ilköğretim mezunu olan çocuklara oranla fen becerisinde ve fiziksel gelişimde daha iyi olduğu sonucu ortaya çıkmıştır. Anne öğrenim durumu değişkeni ile akran ilişkileri alt boyutu dışlanma davranışı arasında anlamlı farklılık görülmüştür. Bu farklılık annesinin öğrenim durumu ilköğretim olan çocuklar ile üniversite olan çocuklar arasında annesi üniversite mezunu olan çocukların lehine bulunmuştur.

Annelerin BCAYKÖ duygusal yeterlik puan ortalamaları ile çocukların DGTT II ince motor gelişim sonucu arasında istatistiksel olarak anlamlı bir ilişki olduğu, DGTT II ince motor gelişim durumu "normal" olan çocukların annelerinin duygusal yeterlik puan ortalamalarının, DGTT II ince motor gelişim durumu "uyarı" olan çocukların annelerinin duygusal yeterlik puan ortalamalarına göre anlamlı derecede daha yüksek olduğu görülmüştür. Bir diğer ifade ile annenin duygusal yeterliği azaldıkça, çocuğun ince motor gelişimi olumsuz yönde etkileniyor. Şahinöz ve arkadaşlarının (2019), cezaevinde annesi ile birlikte kalan çocukların gelişimlerinin karşılaştırılmalı olarak değerlendirdikleri araştırmalarında; ince motor gelişim alanında takvim yaşına göre gecikme gösteren çocukların sayısı cezaevinde annesi ile birlikte kalanlarda daha yüksektir ( $n=12)$. Ayrıca cezaevinde annesi ile kalan çocukların ince motor gelişim alanından aldıkları AGTE puan ortalamalarının daha düşük olduğu görülmektedir ( $>00,05)$. Büyüktaşkapu (2012), annelerin özyeterlik algılarının orta düzeyde olduğunu, disiplin, öğretme ve oyun alanlarında kendilerini daha az yeterli hissettiğini; 1-3 yaş arasındaki çocukların en çok ince motor gelişimlerinde yetersizlik olduğunu, kaba motor, dil-bilişsel ve sosyal beceri-özbakım alanlarında ise yarıdan fazlasının gelişiminin yetersiz olduğunu saptamıştır. Yavuzer (2007)'e göre anne çocuk ilişkisinde ten temasının önemi büyüktür. Annenin kokusu, vücut 1sısı, bebeği tutuş şekli bu ilişkide oldukça önemlidir. Özellikle 0-3 yaşta bu ilişkinin sağlanamaması, ilerleyen yıllarda çocukta bilişsel, duygusal, sosyal gelişim geriliklerine ve gecikmesine neden olabilmektedir. Annenin duygusal olarak yetersiz olmasının çocukla arasındaki ilgi ve iletişimi etkilemesi sebebiyle çocuğun gelişimini destekleyecek uygun davranış ve tutumları sergileyemediği düşünülmektedir.

Annelerin BCAYKÖ finansal yeterlik puan ortalamaları ile çocukların DGTT II ince motor gelişim sonucu arasında istatistiksel olarak anlamlı bir ilişki olduğu, DGTT II ince motor gelişim durumu "normal" olan çocukların annelerinin finansal yeterlik puan ortalamalarının, DGTT II ince motor gelişim durumu "uyarı" olan çocukların annelerinin duygusal yeterlik puan ortalamalarına göre anlamlı derecede daha yüksek olduğu görülmüştür. Bir diğer ifade ile annenin finansal yeterliği azaldıkça, çocuğun ince motor gelişimi olumsuz yönde etkileniyor. 0-6 yaş döneminde çocuğun zengin uyaran barındıran ortamda büyümesi çocuğun gelişimine oldukça katkı sağlamaktadır. Ailenin düşük sosyo-ekonomik düzeye sahip olmasının çocuğun yaşının gerektirdiği bazı deneyimlerden uzak kalmasına neden olması sebebiyle gelişimsel olarak bazı becerileri daha geç kazandığı söylenebilir. Literatürde araştırma bulgusunu destekleyen çalışmaların olduğu görülmektedir. Avşar, İbiş ve Aktuğ (2017) çalışmasında 6-7 yaş grubu çocuklarının sosyoekonomik yapıları ile temel becerilerini karşılaştırmıştır. Araştırma sonucunda alt sosyoekonomik düzeye sahip olan ebeveynlerin çocuklarının büyük kas, lokomotor ve nesne kontrol becerilerinin, orta ve üst sosyo-ekonomik düzeye sahip ebeveynlerin çocuklarına oranla anlamlı oranda daha düşük olduğu bulunmuştur. Çömük Balcı ve arkadaşlarının (2015), okulöncesi dönemi çocukların ince motor becerilerine çevrenin etkilerini inceledikleri araştırmanın sonucunda yüksek sosyo-ekonomik düzey ile çocukların ince motor becerileri 
korele çıkmıştır. İşmen (2004)'in, kendisinin geliştirdiği "Aile İçi Çocuk İstismarı Ölçeği"ni kullandı ̆̆ı ve evrenini lise öğrencilerinin oluşturduğu araştırmasında; "Gelişimi destekleme" alt boyutunda ailenin gelir düzeyi açısından fark olduğu saptanmıştır. Bunun yanı sıra, Baykan ve arkadaşları (1995), farklı sosyo ekonomik düzeyde ailelere sahip çocukların "psiko-motor" ve "sosyal-duygusal" gelişim durumları arsında belirgin fark olmadığını bulmuştur. Bulgulara ait farklılıkların çalışmaların örneklem gruplarındaki farklılıklardan kaynaklanmış olabileceği düşünülmektedir.

\section{KAYNAKÇA}

Alnıak, Ş., ve Dinçer, Ç. (2005). Farklı eğitim yaklaşımları uygulayan okul öncesi eğitim kurumlarına devam eden çocukların kişiler arası problem çözme becerilerinin değerlendirilmesi, Ankara Üniversitesi Ĕ̆itim Bilimleri Fakültesi Dergisi, 38(1):149-166.

Andrews, F.M., and Withey, S.B. (1976). Social indicators of well-being. New York: Plenum Press.

Anlar, B., ve Yalaz, K. (1996). Denver II gelişimsel tarama testi Türk çocuklarına uyarlanması ve standardizasyonu. Hacettepe Çocuk Nörolojisi Gelişimsel Tıp Araştırmaları Grubu. Ankara.

Aslan, S., ve Alparslan, Z. (1999). Çocukluk örselenme yaşantıları ölçeğinin bir üniversite öğrencisi örnekleminde geçerlik, güvenirlik ve faktör yapısı, Türk Psikiyatri Dergisi, 10(4):275- 285.

Atış Akyol, N. (2015). Okul öncesi eğitim kurumuna devam eden 5 yaş çocuklarının akran ilişkileri ile ilkokula hazır bulunuşluk düzeyleri arasındaki ilişkinin incelenmesi, Yayınlanmamış Yüksek Lisans Tezi, Marmara Üniversitesi, İstanbul.

Avşar, S., İbiş, S. ve Aktuğ, Z.B. (2017). 6-7 Yaş Grubu Erkek Öğrencilerin Sosyo-Ekonomik Düzeyleri ile Temel Motor Beceriler Arasındaki Farkın İncelenmesi, Spor ve Performans Araştırmaları Dergisi, 8(2):145-153.

Baykan, S., Temel, F., Ömeroğlu, E., Bulduk, S., Ersoy, Ö., Avcı, N., ve Turla, A. (1995). Ankara'da farklı sosyo-ekonomik düzeydeki 0-6 yaş çocuklarının gelişim durumlarının incelenmesi üzerine bir araştırma. Ankara: Ders Aletleri Yapım Merkezi Matbaası.

Bee, H.L., Barnard, K.E., Eyres, S.J., Gray, C.A., Hammond, M.A., and Spietz, A.Z. (1985). Prediction of IQ and language skill from perinatal status, child performance, family characteristics, and mother-infant interaction, Child Development, 53(5):1134-1156.

Belsky, J. (1980). Child maltreatment: An ecological integration. American Psychologist. 35:320-335.

Bernstein, D.P., Fink, L., and Handelsman, L. (1994). Initial reliability and validity of a new retrospective measure of child abuse and neglect, American Journal of Psychiatry, 151:1132-1136.

Bracha, Z., Perez, F., Gerardin, P., Perriot, Y., Rosque, F., Flament, M., Leroux, M., Mazet, P. and Carter, A. (2004). A French adaptation of the infant-toddler social and emotional assessment, Infant Mental Health Journal, 25(2):117-129.

Büyüktaşkapu, S. (2012). Annelerin Özyeterlik Algıları ile 1-3 Yaş Arasındaki Çocuklarının Gelişimleri Arasındaki İlişkinin İncelenmesi, Amasya Üniversitesi Ĕ̆itim Fakültesi Dergisi, 1(1):1830.

Campbell, A., Converse, P.E., and Rodgers, W.L. (1976). The Quality of American Life. New York: Russell Sage Foundation. 
Canbolat, N.A. (2017). Okul öncesi dönem çocuklarının sosyal beceri ve problem davranışları ile ebeveynlerinin duygusal zekâ düzeyleri ve yaşam doyumları arasındaki ilişkinin incelenmesi, Yüksek Lisans Tezi, Gazi Üniversitesi, Ankara.

Cicchetti, D., and Lynch, M. (1993). Toward an ecological/transactional model of community violence and child maltreatment: Consequences for children's development. Psychiatry. 53:96-118.

Comuk Balci, N., Bayoglu, B., Tekindal, M.A., Kerem Gunel, M., and Anlar, B. (2016). Screening preschool children for fine motor skills: environmental influence, The Journal of Physical Therapy Science, 28(3):1026-1031.

Diaz, A., Simantov, E., and Rickert, V. (2002). Effect of abuse on health: Results of a national survey. Archives of Pediatrics and Adolescent Medicine. 156:811-817.

Israel, G.D. (1992). Determining sample size. University of Florida.

İşmen, AE. (2007). Aile İçi Çocuk İstismarı Ölçek Geliştirme, Hasan Ali Yücel Eğitim Fakültesi Dergisi, 1: 207-221.

Kaplan, S., Pelcovitz, D., and Labruna, V. (1999). Child and adolescent abuse and neglect research: a review of the past 10 years. Part 1: Physical and emotional abuse and neglect, Journal of the American Academy of Child \& Adolescent Psychiatry, 38:1214-1222.

Kök, M., Tuğluk, M.N., ve Bay, E. (2005). Okul öncesi eğitimin öğrencilerin gelişim özellikleri üzerindeki etkisinin incelenmesi, Kazım Karabekir Eğitim Fakültesi Dergisi, 11:294-303.

Kuyucu, Y. (2012). Duyguları anlama becerileri farklı düzeydeki çocukların (60-72 ay) akranlarına karşı gösterdikleri duygusal ve davranışsal tepkilerinin incelenmesi, Yüksek Lisans Tezi, Selçuk Üniversitesi, Konya.

Masalcı, A.D. (2000). Aile içi etkileşimlerle çocuğun saldırganlık düzeyi ve uygun davranışının karşılaştırılması, Yayımlanmamış Yüksek Lisans Tezi, Dokuz Eylül Üniversitesi, İzmir.

Meral, B.F. (2011). Gelişimsel yetersizliği olan çocuk annelerinin aile yaşam kalitesi algılarının incelenmesi, Doktora Tezi, Anadolu Üniversitesi, İzmir.

Meral, B.F., ve Cavkaytar, A. (2013). Beach center aile yaşam kalitesi ölçeğinin Türkçe uyarlama, geçerlik ve güvenirlik çalışması (Turkish adaptation, validity and reliability study of the beach center family quality of life scale), Eğitim ve Bilim (Education and Science), 38(170):48-60.

Öz, İ. (2003). Çocuk ve Aile. Ankara: Kök Yayıncılık.

Şahin Dağlı, F. (2017). Aile içi iletişim: Ailelerin çocuk yetiştirme tutumları ve olumlu ebeveynlik, (Editör) Gökçay, G., Beyazova, U.: İlk beş yaşta çocuk sağlığı izlemi. İstanbul: Nobel Tip Kitabevleri.

Şahinöz, A., Sağın Küçük, N., Çuhacı Çakır, B., Kara Uzun, A. ve Durualp, E. (2019). Cezaevinde Annesi ile Birlikte Kalan Çocukların Gelişimlerinin Karşılaştırılmalı Olarak Değerlendirilmesi, Ankara Üniversitesi Tip Fakültesi Mecmuası, 72(1):66-75.

Şen, S., Çiçekler, C.Y., ve Yılmaz, R. (2010). Okul öncesi kurumlarına devam eden ve etmeyen 56 yaş çocukların üstdil becerilerinin incelenmesi, Ondokuz Mayıs Üniversitesi Eğitim Dergisi, 29(2):37-54.

Ünver Bağcıoğlu, G. (2015). Gelişimle ilgili temel kavramlar, gelişimin temel ilkeleri ve gelişimi etkileyen faktörler, (Editör) Ulusoy, A.: Gelişim ve Öğrenme Psikolojisi. Ankara: Anı Yayıncılık.

Yalaz, K., Anlar, B.U., ve Bayoğlu, B. (2016) Denver II gelişimsel tarama testi. 2. Basım. Ankara: Gelişimsel Çocuk Nörolojisi Derneği. 
Yavuzer, H. (2007). Ana-baba ve çocuk. İstanbul: Remzi Kitabevi.

Yavuzer, H. (2008). Çocuğunuzun ilk 6 yılı. İstanbul: Remzi Kitabevi.

Yener, P. (2014). Okul öncesi eğitimi alan 60 ay ve üzeri çocukların sosyal beceri düzeyleri ile annelerinin çocuk yetiştirme tutumları arasındaki ilişkinin incelenmesi, Yüksek Lisans Tezi, Gazi Üniversitesi, Ankara. 